\title{
TOWN, COMMUNITY, AND MULTICOMMUNITY
}

\author{
The Theoretical Implications of a Guatemala Case
}

By Rubén E. Reina

University of Pennsylvania.

About twenty-five years ago anthropologists began to focus on the study of small modern towns. To those who, like Redfield, were concerned with community studies, the "little" communities appeared to be "another of those prevailing and conspicuous forms in which humanity obviously come to our notice." (Redfield, 1960, p. 1). An examination of the literature shows that through the study of villages and towns we have come to understand one of the most basic organizing social principles particularly important among modern Latin American people. ${ }^{1}$

The ethnographic data secured in the studies of Latin American towns and the study of special aspects of life in the context of the entire system have been the basis for the construction of typologies which have indirectly furthered the conceptualization of community as another form of social organization. Therefore, community in Latin America does not refer to just any group of individuals joined by a profession or a common interest; rather, community constitutes a definite arrangement within the area of social organization in which the life of modern Latin American man can be better understood.

1 We may agree that this type of organization appears neither basic nor similar to that in Africa or in India where people are viewed and classified through the principle of lineage and caste respectively. These principles, and not that of community, have been presented to us as the most basic organizing principles of those two areas. Although Latin American pueblos present variations, there is, in most cases, an intense identification of the people born in or "adopted" by a town; it may even be said that they derive their dignidad via the town of their birth or residence. It is in this context that "community" acquires a very special meaning in the framework of social organization. 
In the Guatemala Highlands the corporate community type discussed by Wolf prevails among Maya people (Wolf, 1953. pp. 456-61) Chinautla, where the author has worked for several years (Reina, 1960) is an excellent example of how this community type functions. Throughout the years of field work in this area, it became evident that the central aspects of Chinautla's culture were contained within the physical boundaries of the town. It is also interesting to note that the historical and psychological dimensions coincide with the physical, forming a powerful entity. In Wolf's words, "relationships of individuals and kin groups within the community are bounded by a common structure... [and] the community aims primarily at maintaining an equilibrium of roles within the community in an effort to keep intact its outer boundary. Maintenance of the outer boundary reacts in turn on the stability of the equilibrium within it." (Wolf, ibid., p. 463) The phrase of the Chinautlecos, "the law of the saints," was a central guidepost of the community culture which brought forth a centrifugal movement of all el. ements of the town. Without a doubt the individual born in the pueblo "carries the culture of such community... actively", (Wolf, ibid., p. 460) a culture which is distinctive and meaningful to him only within Chinautla. Chinautlecos are ready to defend it tenaciously, as can be seen through their history since the 16th century, and particularly during the last decade of the present century. (Reina, 1959 b.) For our purposes here it is worth noting that the Chinautlecos' sense of corporateness maintained them apart, to the extent that they did not feel a part of any intervillage system, nor did they wish to find cultural similarities with other communities comparable to theirs. Migration was viewed as a very difficult if not an impossible undertaking. Only those Chinautlecos elected to serve in the political structure of the town recognized ties to the nation. Even those in dividuals who were constantly involved in business transactions in the Guatemala City markets considered such associations only a practical arrangement in support of Chinautla's unique way of life. A Chinautleco felt that because he was born in the town of Chinautla it was his duty to support and observe actively a tradition prepared by his ancestors; and he was not to modify it.

In contrast to the corporate community type among Indians of the Guatemala Highlands stand towns of the Peten, northern lowland Guatemala, which are closer to the open-type community 


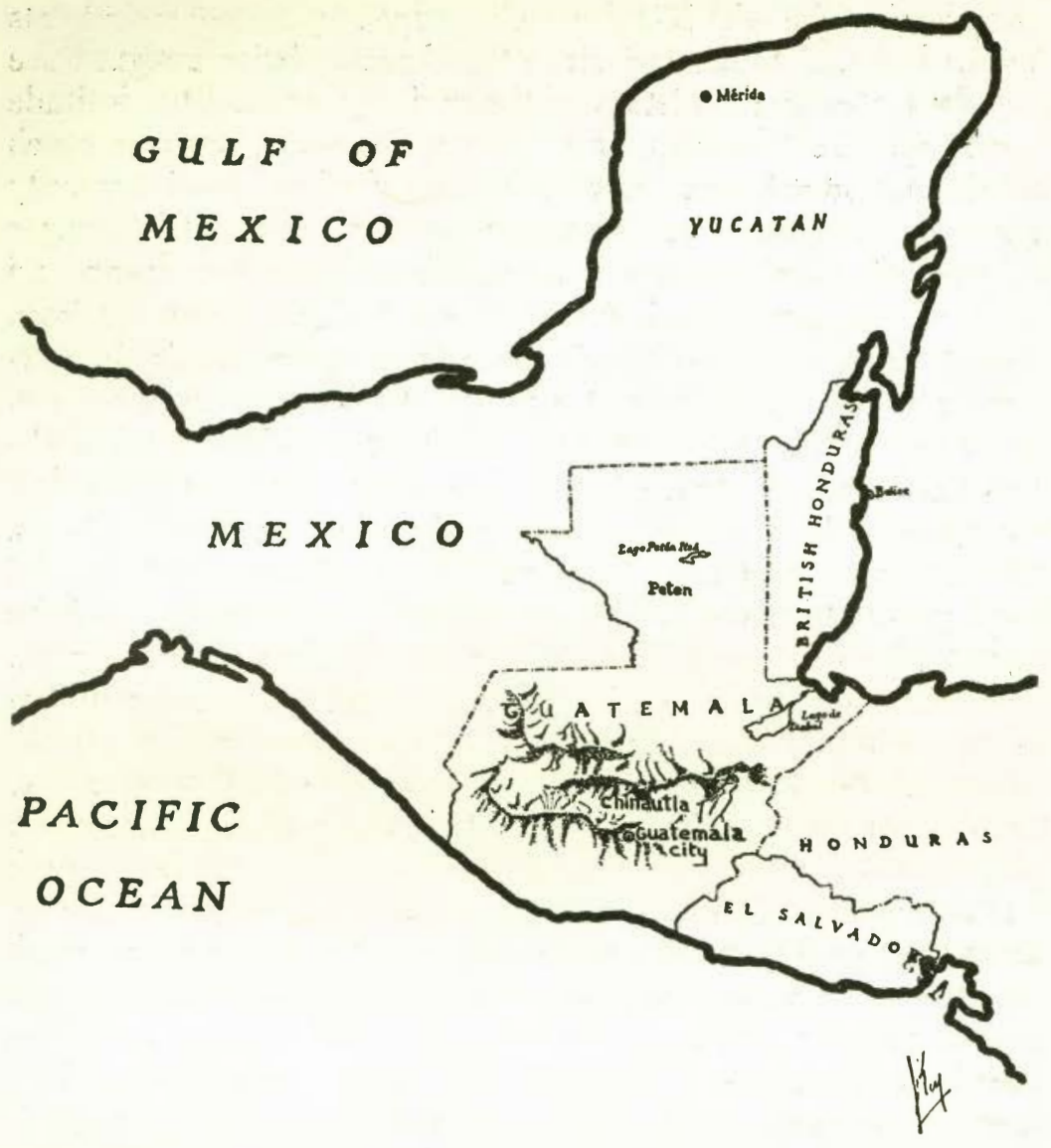

(Wolf, ibid., pp. 461-66) and are to be the subject of this paper. Peten towns ${ }^{2}$ are open in the sense that they welcome interaction; they feel themselves a part of "the outside world and tie their fortunes to outside demands." (Wolf, ibid., p. 462) This is true of both Indian and non-Indian towns. The situation leaves each town in open competition and the inhabitants are in turn theoretically free to move in or out of the town of their birth. Although the mobility is feasible the move may be complex because the person, by taking a new residence, acquires the town's char-

2 Town is used in reference to that human entity which, as a physical unit, las a political status and appears more as an "urban" residential unit. It corresponds in Latin America to the concept of "pueblo." 
acterization. He will be personally judged by the measurements applied to that town; and since the characteristics assigned are deeply rooted in the history of the region, there is little latitude for escape. To take up new residence, therefore, requires much thinking, and it is generally only because of economic necessity that one moves. It was this migratory process and the changes of identification which put in relief the actual meaning and nature of the inter-town linkages for the region. Because in Peten people evaluate each other via the town, and since social interaction is relatively frequent they come to form an intricate network which I have chosen to identify as multicommunity. Peteneros, in contrast to the Chinautleco view, live their public life by a code which is not altogether of their own making. Thus, while Chinautlecos are aloof and indifferent toward others and hardly care to make evaluation of individuals in terms of the place of residence, Peteneros are quick to make judgment. Therefore, the social setting of Peten cannot be fully understood without considering the lattice formed by the towns. ${ }^{3}$ The reference to each other's town is central in Peten because it impels a mode of public interaction which at the same time, permeates the economic, political and religious life of each town. Judgment and evaluation of each other is then more strongly group-oriented than individual-oriented. In sum, each town is more than a physical and political entity. Each is a community for its culture; and the acceptance of each other as members of a town with its particular orientation links them in a special way, bringing about a superstructure which is the multicommunity.

Because the case of Peten offers interesting insights into social organization and the matter of culture dynamics, I would like to offer a preliminary report on how Peteneros perceive each other and affert each other, perpetuating an overall way of life within the area and in turn within each town. The case could be significant beyond Peten, particularly in Latin America where much attention is given to economic development and change.

3 The importance of the intervillage network in Latin America was discussed recently by Young. He analyzed the intervillage relationship in Mexico by means of sociometry, "... except that the units are villages rather than people." (Young, 1964, p. 36) He defined the intervillage system as "the functioning unit of villages that have more frequent and varied group-level relationships with one another". 
The paper opens with a brief exposition of the Peten heritage and its settlements. It is necessary to familiarize the reader with the general background for a better understanding of the conclusions made later. The next section is concerned primarily with sentiments and attitudes toward each of the pueblos. For organizational purposes of this paper I shall describe relationships viewed from the "city" of Flores, most important town, capital of the department, and classified as city for its political role. Relationships, images, and sentiments among other Peten towns, as well as among those Peteneros residing in Guatemala City, will be descrihed. In conclusion, a number of patterns will be selected for discussion because of their implications for a special type of social organization and change. ${ }^{4}$

\section{Peten and Its Towns}

The Spanish colonization of Peten began after 1697, when the native population of Itzas had been conquered. The region received Yucatecans of Spanish, Mexican, and mixed origin, and later runaway slaves from the plantations of British Honduras. These people constitute the main population layer of Peten. They and some Central American Spaniards and Syrian arrivals settled in pueblos which were primarily involved in the exploitation of lumber along the rivers and chicle in the forests. This resulted in the formation of some aldeas, but the story of aldeas has usually been short; they appear and disappear with the rise and fall of outside economic demands.

Peten is a Department with an area of 14,000 square miles, heavily forested, with a population of about 15,897 (1950 Census). The pueblo population is distributed as follows:*

"City" of Flores and capital of Peten located on an island in Lake Peten-Itza ....................... 1,574

Pueblo and head of municipios:

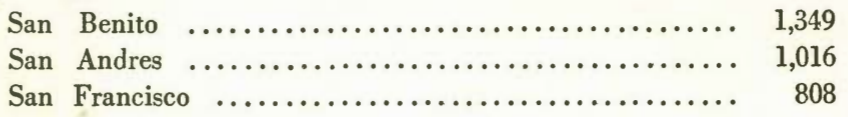

4 . The fifteen months of field work was sponsored by the National Science Foundation, Grant No. 11573, 1960-61. I am grateful to the National Science Foundation and the University of Pennsylvania Museum for their generous assistance. The author wishes to thank Dr. Igor Kopytoff for discussing the subject of this paper with him.

* See map. 
La Libertad ............................. 632

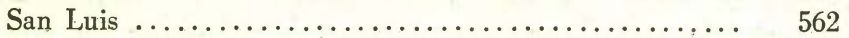

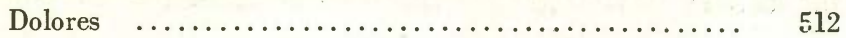

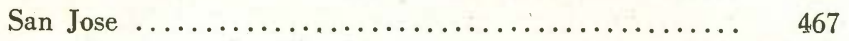

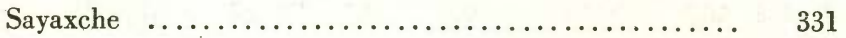

Santa Ana ................................ 189

Aldeas, chicle camps, and Census errors ........... 7,457

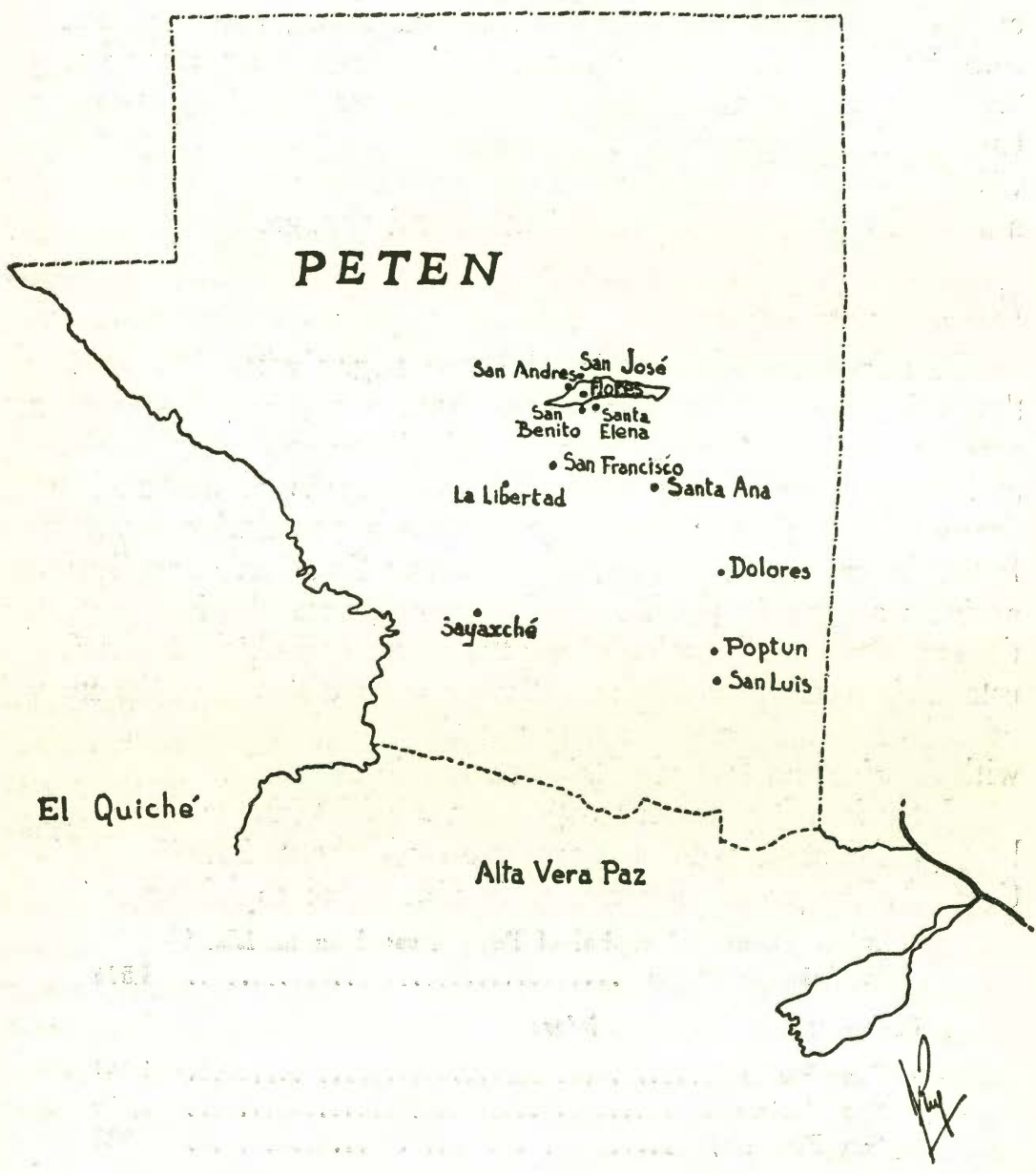

Therefore, a total population of 7,440 people claimed residence in pueblos, all heads of municipios. The "city" of Flores and these pueblos have been responsible for the regional political and economic development of the Department during the past 200 years. The puehlos have a share in the history of Peten 
because of their participation in the economy, politics, and religious life, all centrally located in Flores.

In the context of a frontier existence, they have faced together serious crises due to cyclical crop failures, grasshopper plagues, the effect of long isolation during the six-month rainy season, and the economic collapse during the world depression. Under such adversities the people's identity with the Peten took form, and there remains a strong social element among those families who bravely withstood the hardships of life in those critical days. Because of this, they feel that Peteneros possess a distinctive quality, compared with the rest of the nation's population.

Beneath the undertones of egalitarianism and "perfect democracy" one finds strong discrimination based upon the reputation of the community. History shows much intercommunity struggle, deprivation, legal injustice, and economic exploitation, as well as periods of prosperity. This could be the basis for an adequate explanation of the rise and solidification of their differences and characterization of each pueblo's intrinsic "personality." The interaction in this setting constitutes the central subject matter for this paper.

\section{Florentinos Define Themselves}

The Florentinos, who live on a very small island in the Lake Peten-Itza, show a very strong pride in their ancestors' pioneer efforts and accomplishments in the jungle. The intellectuals, more than the lower, middle, and business groups, pride themselves upon inhabiting the region where the Mayans reached a very high level of development. An almost mythical view is held of the Itza, who had met Cortez and defended the lake region against the many attempts at Conquest. The mixing of Maya and Spanish is, from a theoretical and poetical viewpoint, positively acknowledged. One finds statements which show with what great pride they view their area. In a monograph, a retired Flores teacher poetically stated,

Peten is one of the Departments of Guatemala with fewer Indians, because in their own pueblos they have mixed with Ladinos. Many Guatemalans believe that to go to Peten is to arrive in Siberia or Central Africa. Those who think in that manner should be reminded that Her- 
nán Cortés only four hundred years ago went through this jungle aided only by his courage. A trip to Peten by plane is no longer a strange and exotic undertaking. One is provided there with good food and medicine. ${ }^{5}$

The Florentinos' efforts to erase the public notion that Peten is not a desirable place are constant.

In many ways the Florentinos feel they have no kinship with other Guatemalans. Foresı entrepreneurs are frequently engaged in a quiet struggle with government administrators residing in Flores. The struggle has its roots in the Florentinos' assumption that one of the primary objectives of the Government is to exploit the natural resources, resulting in exhobitant profits which the intruders enjoy outside Peten. It has also to do with the concept of private property on national land which gives the owner only a provisional property title. In cases of inheritance, sons and daughters in effect receive the rights to continue "administering" the use of the land. Therefore, banks will not acknowledge this type of property as collateral for loans or for other transactions affecting economic development of the Department. Florentinos summarize the situation in the following manner: "Peten is no more than a finca for Guatemalan presidents, and the selfish interests of past governments have contributed to the paralyzation of progress." The politics of rights over the land brings out a feeling of being exploited, and causes repercussions in the economy; and, most important, it brings a social gap between "they," the Guatemalans ${ }^{6}$ and "us," the Peteneros. In their views this situation is incompatible with their self image. "We," stated an informant, "are gifted individuals, backed by a glorious history, and we can demonstrate that we are more capable to lead and govern our people than Guatemalans."

The perplexing fart is that they do not translate their feelings into aggressive action. To the contrary, they like to maintain a very pleasant interaction with others. But this high degree of social formality observed in Peten troubles Guatemalan businessmen who, after an agreeable exchange of ideas and prom-

5 Soza, p. 146.

6 The term "Guatemalan" is used to refer to those people of the Highland :areas, particularly of Guatemala City. 
ises, see a lack of initiative and motion. Flores intellectuals pride themselves on the belief that in Peten society the dignity of man is promoted by the practice of egalitarian principles, and this is possible only in a "perfect democracy" as it exists among Peteneros.

To Cuatemalans this is an inconsistency because while the intellectuals of Flores will say to outsiders "We have a perfect democracy", anyone curious of their ways of life could recognize much internal social discrimination in terms of social classes and towns. Therefore, to the outsiders, "Florentinos are egocentered", affecting their participation in programs and projects brought to them. They type Florentinos as obstinate, as people whose real feelings are difficult to know because "they cover everything with a veil of high formality and agreeable good manners; but their true feeling is the opposite". Their strong individualism, translated as "No one orders us around", ( $a$ nosotros no nos manda nadie) is recognized as the all-important theme, perhaps most needed in a frontier setting.

The fact is that Florentinos are aware of their own image and also of outsiders' reaction. It would seem to function as the very shell that protects them in a very complex social game. By not opening up to outsiders they surround themselves with an aura of dignity and mystery, making it very difficult to penetrate and understand, particularly when the outsider does not possess a knowledge of the social history of Peten.

Florentinos can be characterized as highly urban. (Reina, 1964, pp. 265-78.) They pride themselves on being the bearers of city ways and, to some extent, they have been able to achieve an exceptional city orientation; they pride themselves on their low incidence of crime and absence of extreme poverty that are found in other cities. In a sense, the population of Flores, highly concentrated as it is on the island and away from the direct association with the land, has prompted a way of life distinguished as urban.

The cultivation of this urban image is highly valued. The lack of modern conveniences does not affect the role Florentinos play as people of the "city." They consider people from the pueblos as peasants. The difference between ecology of "city" and town is not outstanding. But the Florentino feels that it is the person and what he himself appears able to do that gives the degree of sophistication necessary to be of the city. The weight 
placed on courtesy, alertness, intellectuality, literacy, leadership in civic affairs, and some knowledge of world affairs makes Florentinos, by contrast, the most urbanized people in the area.

A strong belief that they are endowed with an "innate superiority" appears to be a basic motif translated culturally in various ways to their children during the early years of socialization. When the children become adults, this sense of superiority is deeply embedded. For those who move to Guatemala City, this feeling seems to keep them apart from other Guatemalans. Success of Peteneros in the professions, political careers, entrepreneurship, and journalism are frequent topics of conversation with ontsiders and among themselves. Concomitantly along with those favorable comments for those who have achieved intellectual recognition are criticisms of some who have followed "their selfish interest and lost loyalties to the Peten heritage" and "sold their souls, forgotten their land, and cast shame on their own 'race'."

In Guatemala City the Petenero Club acts as a coordinating institution, boosting their morale and strengthening their identification. When together they consider themselves migrants and tend to evaluate negatively the social conditions of the big city. "In this city," stated an informant, "one cannot find spiritual peace." Their sentiment is strong and has carried through two generations, while they continue to feel themselves political exiles. They are in Guatemala City because the economic conditions of Peten offer no possibilities, but the attachment to their homes is such that if the economy would provide them work, most would return. In the meantime, they are supercritical of the national government as well as of foreign enterprise, which mutually disregard the dignity of the Peteneros and manage to exploit both the natural resources and the people.

Marriages between Florentinos and Guatemalans have occurred and are held up as examples of the high quality of the Petenero. But the idea prevails that "it is more desirable to stay with that which is known." Flores remains as the ideal place in which one should live and marry. It is "clean, quiet, and peaceful," particularly when contrasted with the evil of a big metropolitan center like Guatemala City. 


\section{Florentinos and the Mayeros of San José}

Having outlined some of the major features of Flores' selfimage, we may now describe the relation between Flores and San José. Just across the lake, a matter of two and one-half hours by heavy dug-out canoe, is San José. The area has been cleared of large trees, leaving the clear line of the forest in perfect view. By the style of the houses and the old women's dresses, one can be sure that this pueblo is of Maya ancestry. It has fewer than 500 people, some of whose family names coincide with those mentioned by the conquistadores of 1697 . They still speak Yucatecan, but the accent and some lexical variations differentiate them from those in the Yucatán peninsula. There seems to be sufficient evidence that some of these families are direct descendents of the aggressive Itzas who dominated the lake region for almost 200 years after the conquest of the Yucatán.

San José, the most Maya pueblo of all Peten (Reina, 1962), has played an important role in support of the Flores economy. In the eighteenth century, officials demanded the services of the people in the name of law and for the development of the nation. Through the tequio (municipal duties) system, taxpayers were used as domestic servants and as runners to transport mail and merchandise to and from Coban in the south, Cayo in British Honduras to the east, and Tenosique, a Mexican town to the northwest. Furthermore, they were ordered to produce as many crops of maize as possible and were contracted to bring lumber, posts, and palms from the forest for the construction of houses in Flores. Colonial officials, in order to assure themselves of efficient service, frequently appointed a community governor who was encouraged to apply his power as cacique and who developed at times a true satrapy. Because of this harsh treatment, San Joseños suffered a substantial loss in the population, and relocated themselves in the nearby British territory. San Joseños can trace their descendants to the Itza, and Florentino intellectuals have enjoyed supporting their historical reputation in an effort to distinguish them from the Lacandon Indians or those of San Luis, southern Peten, whom they consider less civilized. This distinction is, from their point of view, in order, and "explains a high quality of people among the San Joseños with the potentiality for achieving progress." Some San Joseños have demonstrated their abilities to their Flores 
neighbors, as for example the "self-made" lawyer (uisache), who is also a retired "teacher" of this Maya community; he is frequently hired by the poor individuals of the lake towns for their defense in court. He is cited as a prime example of what San Joseños are capable of achieving. But only exceptional cases can be thus cited, because the population at large is looked upon as possessing the characteristics of being crude (tercos), independent, and highly illiterate - characteristics hindering further progress and "civilized" achievement.

The Florentino officials and clergy resent the San Joseños' aloofness, but no one denies that they are extremely skillful in the forest and that the "city" derives substantial benefits from their abilities. However, their passive and polite resistance in business and official transactions is the cause of much discord. "They do things when they want to" is the view held by the Florentinos. On this specific point a Flores man teaching in San José stated that even children in school show an extreme independence which is supported by their parents: "The life in the forest is the main topic of conversation, and it is hard to develop an interest in school subjects. They prefer to live alone, almost like animals, keeping their low standards and developing no further ambitions in life." This thought is held not only by Florentinos, but by other pueblo people who compete for the status of their community. Florentinos and puebleros (non-Maya) share quietly the same views toward San Joseños. However, a Florentino will not hesitate to enter into the relationship of godparent with a San Joseño. Those of the upper group do not appear overtly anxious to accept the responsibility of godparent, but will not refuse to do so. But those of the middle group seem to welcome the opportunity to serve at baptisms and weddings. This relationship has found its rewards, particularly in historical times when there were shortages of grain and food. Today, because of the characteristic generosity of San Joseños towards "co-parents." Florentinos derive fringe benefits from a well-cultivated ceremonial, as co-parents bring abundant presents of meat from wild forest animals and horticultural products. Chicle contractors can also depend on the best San José labor to come to them during the chicle season.

Regardless of the benefits derived from a very smooth relationship, there is nevertheless, a reserved attitude toward the San Joseños because of their Indian heritage. A professional 
Florentino stated that although they are culturally Mayeros, "their Indian blood carries a hidden savageness for which they cannot be trusted. At any unexpected moment they may kick back." This view was shared by others from the same class. The same thought was expressed in the nineteenth century, when one of the most prominent Flores figures said, "In San José only the patron saint is good and can be trusted." Yet, as descendents of "pure Indian blood of the Maya civilization," San Joseños are considered by Florentinos more reliable than a group of mixed blood of whom "one must be extra cautious," as is the case of one of the pueblos of the lake.

San Joseños are welcome in Flores, for their products are needed in the city's daily diet. But Florentinos will readily point out to a stranger the difference- in appearance between San Joseños and themselves. "They look different, even awkward," stated a Flores businessman.

San Joseños are seldom entertained socially in private homes. When a business transaction has been completed, if the weather is favorable for a crossing of the lake in their dugout canoes, San Joseños will begin their return home before noon. Very few of them, it was explained, understand the social rules, and to avoid personal incidents, particularly under the influence of alcohol, relationships are purposely maintained at a business level. "They take confianza to represent an emotional friendship and are not capable of drawing the lines."

San Joseños, nevertheless, strongly sense and resent this quiet ethnic discrimination that exists in an atmosphere of what only seems to be toleration. They readily point out a lack of sincerity and explain that they are exploited in the situation. "The Florentinos," San Joseños say, "are muy interesados, proud, selfish, and some would like to treat us as if we were low people." On the other hand, San Joseños are capable, at times, of looking at some situations with good humor. Through a god-parent, co-parent, or patrón, they find interesting pieces of gossip about Florentinos, and this may become a source of talk at home. Usually it centers about a poor Flores inhabitant who wants to appear rich ("se las tiran de ricos y civilizados"). San Joseños find it ridiculous that someone wants to be what he was not made to be. "He is just like Florentinos say we are, but doesn't want to admit it. .." 
Having described the social image at a personal level, let us look at the situation from a group level. Officials have maintained a long-standing feud for the right to national land. Florentinos and San Joseños both wish to be administrators of national reserve land hecause the municipio of San José contains rich areas for the exploitation of chicle from the zapote trees. The land in dispute was under San José's municipal jurisdiction before the age of rubber and chicle. Now the land is an excellent chicle-producing area, bringing a large revenue, which Flores officials argue San Joseños do not need. Florentino officials tend to support their argument by drawing illustrations from the "misuse" of large sums of money by San Joseños. The most vivid recent event was the erection in San José of a modern dance hall with materials flown in directly from Guatemala City. It was an investment of over $\$ 10,000$. Florentinos ridicule this modern building, which is seldom in use and appears odd and out of place in a community of a handful of Maya-style houses. Yet, San Joseños feel that the building is more than a dance hall; while under construction it was a means of providing the local people with added income. And it was a symbol of their administrative independence. San Joseños thought it wise to invest rapidly in a community project before their money might be taken by others in a time of national economic instability. Now jokingly they say, "Anyone can come and remove our building - if they think they can." Florentinos are quick to point out that San Joseños are in fact little concerned with the rapid deterioration of this public building in the tropics, which represents a loss, and argue that San Joseños are not sufficiently advanced for such sophistication.

The "race" concept has been important in the formation of the Florentinos' self-image and separation. In the words of an elderly and sophisticated informant, "The crossing of Indians, non-Indians, and Negroes is bad because it degenerates the blood. The blood of the Negroes and Indians is strong and it will predominate. In the eyes of religion we are all equal; but to us here there is a difference because of the harm of intermixing. Our blood is very delicate." Because of their assumptions relating racial features with personality types, some of the "crossed blood" families are readily classified, and their behavior explained in terms of their racial streak. 
In summary, it may be said that hostility toward San José is carefully controlled and it rarely finds expression in any public form or custom. The positive sentiment toward San Joseños is practical and convenient in a frontier existence. San Joseños' ability in the forest and reliability as producers for a weekly market is quietly welcomed by Florentinos and they hope that this role will continue. However, their negative position toward San Joseños from the standpoint of racial difference, low education, "Indian" personality and low degree of civilization counter-balances and outweighs the positive evaluation, leaving San Joseños sorially alone, secluded in their own pueblo, interacting only on the economic and official level, and discouraging marriages on account of their basic physical and psychological differences. Any Florentino taking residence in San José is said to be a person of the same quality and potential as San Joseños.

The end-result is reduced to the formula that San Joseños possess a "private sentiment," a strong factor against further social interaction. This "private sentiment does not permit San Joseños to seduce a woman from Flores," leaving, from Florentinos' viewpoint, a balance in their favor, assuring the Florentinos that their women will not be disturbed.

\section{Florentinos and Non-Mayan Peteneros}

Florentinos are uncomfortable when a social and physical separation cannot be clearly outlined. Places like La Libertad, San Francisco, and San Andrés correspond to the rural Ladino pueblos of Highland Guatemala, and a real effort must be made to show differences which are not based upon the same common denominator.

The desire on the part of Florentinos to point out differences with those people of the same origin is evident. The three communities mentioned above which compete are described as possessing dialectical differences. The speech of each is charac. terized by a different intonation, known as pujado. The sharper or stronger the pujado, the more convincing the argument that the people of the pueblos have not arrived at an equal "level of eivilization." The Flores lower class compete socially with the pueblo people; but the economic upper class Florentinos support the poorer residents of Flores by pointing out their social accomplishments and by emphasizing their success in 
dealing with matters of the modern world. The lower group capitalizes on this favoritism and, in private, readily makes discriminatory statements loaded with social sarcasm about those rural Peteneros who are different in their life in the forest: they are, like all Indians, they say, ignorant, with "funny ideas," and they are known by "ridiculous" personal names, such as Light, Star, Hope, Belgium, and Carnation; they distinguish themselves in public by their style of dress, by wearing dark sun glasses at night, etc. These pueblo people, Florentinos will say, not only possess a different orientation, but display a distinctive temperament, attested to by the harsh treatment given their wives. To the Florentinos' way of thinking, pueblo wives are overworked and badly treated. In the light of this network of opinions, it is not at all difficult to explain endogamy. The first choice for marriage is within one's own community and within one's own class of people; it appears that only when the chances are greatly reduced will a person consider someone from another pueblo.

When ethnic and material cultural features are not readily recognized, then a public social event which is noted for its exotic touch may be used to demonstrate that the subtle differences in quality between the people of Flores and those of the pueblos are real. In one of the most non-Indian pueblos, a Protestant sect has been very active since 1929 . The activities became popularized in 1946 with the coming of an American missionary. The information collected reveals that the conversions of non-Indians relate to their dissatisfaction with the pueblo style of life, with their high aspirations, and their frustration with the present economic system. With the coming of the Kekchi people from the Highlands, two Protestant sects branched out, and in the summer of 1962 one group held several days of active religious revival services. On the last day, the pueblo became greatly excited when over twenty adults of both sexes remained behind locked doors, talking unintelligibly and making strange sounds. Some mothers of the pueblo, whose daughters had come to the service, became alarmed and went to the local authorities to request help. The commander-in-chief of the police force in Flores secured permission from the judge to open the doors. In the high tropical heat, thirsty and hungry, this group had remained in a small room for almost ten hours. The police found some of the leaders with little clothing. The turmoil in the 
pueblo was tremendous, and the participation of the Flores authorities made the situation a Departmental matter. A variety of versions were brought back to Flores, claiming that atrocious sexual orgies had been held. Flores' lower groups pictured clothing "dripping with blood" from virgin girls abused by a leader who wanted to illustrate evil things. As the versions went from mouth to mouth in the city, the religious revival was greatly exaggerated. The intellectuals' interpretation took the color of a true messianic movement, as described frequently by anthropologists for other areas of the world. In almost anthropological terms, the intellectual elite, in their own way, speculated upon the role of the leader as a prophet, upon the use of drugs to induce trance, and upon the mentality of the followers who believed the end of the world was near and that they were the chosen people of God.

The embarrassment of the people in the pueblo where it took place was obvious as Florentinos speculated upon the degree of savageness, salvajismo, manifested in this Pueblo. Catholics turned to their Church, making the sign of the cross and spreading holy water around the ground where the meeting had taken place, and over the people confined in the local jail. Their religious fervor at this time was in striking contrast to the usual apathy toward church services. Some of the people awaited eagerly the arrival of the priest for confession, in fear of the evil that had come to the pueblo for the first time. In the market activities on the Flores beaches there were many groups awaiting news, and those arriving from the pueblo now insisted that they were of good Catholic tradition.

Interestingly enough, the other communities examined themselves in relation to this event, concluding that, in the absence of similar incidents, they could claim to be more civilized, and Florentinos took pride over all others in having only two families converted to Protestantism. This incident provided many insights into the nature of Peten society. It was explained by city informants to be "all due to the simplicity of these people of pueblo life, whose state of evolution and sentimentality leads them to experience fantasy which they wish to convert into reality." Everyone, however, agreed that the entire incident should be kept within the Department because it would not enhance the overall reputation of Peteneros in Guatemala City. 
Without a doubt, it was a convenient incident to prove once more some of the fundamental differences, and even more, some of the individual quality differences, among the various groups within the Peten society. It points to the presence of two traditional orientations in the Peten, namely that the "city" people and the "pueblo" people are endowed with characteristics that are qualitatively different. And this is considered the basis for any future social development.

The pueblos of La Libertad, San Francisco, Sayaxche, Santa Ana, a section of San Andrés, and the most important aldea, Santa Elena, all claim white ancestry via Mexico. Their Spanish ancestry is most important to their public self-image; they are capable of "civilized achievements." But what separates these pueblos from Flores is their country-like attitude and "lack of intellectual interest." Although they are officially classified as Ladino, the concept does not carry the same distinction as among the Highland people. They are all "Peteneros," the one single concept for all and thus the importance of the community stereotypes. In these pueblos, however, people are recognized by Florentinos for their high aspirations in life, perhaps too high to be easily achieved. They are without a doubt "as Petenero as Florentinos, but with a low degree of 'culture' or 'civilization'." They are known for their ambition to possess luxury items at the expense of good food or medicine. Furthermore, they are apt to follow closely and believe in the predictions made in horoscopes published in the national Guatemala newspapers. They are recognized as hard-working people, producers of staples to whom Florentinos, as "city" people, owe recognition. But they do not get along among themselves, and, contrary to the other group of communities, they extend this aggressiveness toward Flores.

The community of San Benito was established by runaway slaves from British Honduras, and although in the last few years it has received a large variety of individuals, it carries the reputation of being a Negro community; this is the important basis for the community social reputation and low esteem. San Benito has shown rapid growth in the last few decades. The rivalry between Flores and San Benito has intensified to the extent that any general public community function is noted for quarrels and fights between groups of teenagers from these towns, supported by adults, members of the pueblo. 
San Benito is adjacent to Santa Elena aldea, both located across a very narrow arm of the lake which separates them from Flores. The expansion of both has buffeted Flores in business competition because they can expand, while Flores is embottled on a small island without possibility of physical expansion. San Benito presents itself as an open community, attracting non-Peteneros. Large numbers of Kekchi people from the Alta Vera Paz have relocated there and are currently attracting their relatives. San Benito has the reputation of having bars and houses of prostitution with Ladino women from Highland Guatemala towns. A new Spanish priest has given San Benito the label of "the sewer of the Peten." So far the clergy has been unable to muster enough influence to eradicate those centers.

In general, Florentinos characterize San Benito as composed of "bad people of low morals." Some consider it a gay place, though poor due to laziness; "they do not like to work in the forest."

San Beniteños are distinctive for their display of decorative items and for their brightly colored style of dress. Without a doubt their proximaty to Flores (five minutes crossing by boat) has developed among them a strong group identification defend. ing one another as they face Flores competition. Their hostility is expressed when Flores boys visit their town. In some cases they follow the practice of running the visitors into the lake. This ambush situation may be of long duration if officials do not intervene. San Beniteños have the reputation of being very contentious - muy pleitistas - with outsiders. Seldom will individuals from San Benito come across to visit Flores; only in cases of necessity when the services offered by the city are essential will they make the trip. Although the physical proximity to Flores is hardly an impediment for interaction, there is little contact; there is more with San José and San Andrés than with San Benito.

There is a group of towns and settlements to the south of the lake, separated by savannahs, forest, and rivers. The roads are precarious and it has been only in the last few years that a fairly adequate route has been opened. Yet the twenty-minute flight by DC-3 three times a week is the most reliable means of transportation. Poctun, for instance, is an old settlement recently redeveloped in support of military installations and 
agricultural experiments fostered by the Fomento y Desarrollo del Peten (FYDEP). This large town is still an aldea and since it does not share the same historic events with Flores and the lake pueblos, it neither competes nor enters into the social organization of Central Peten. Sayaxché is another town isolated by the crossing of a tributary to the Usumacinta River and, by the composition of its population, is socially part of the Alta Vera Paz Department.

The town farthest to the south of Flores, San Luis, is composed of Indians "most backward" in contrast to the communities of Dolores, San José, and a sector of San Andrés. Florentinos feel that the pueblos of Maya-Yucatecan origin are of "bettetr blood" than the Indians of San Luis, qualitatively different from the composite of attributes which are taken to be Florentino. Florentinos regard the Indians of San Luis as very poor and without "culture" or civilization, as crude, easy to trick, submissive, and contentious among themselves, though harmless toward outsiders, and very reserved and shy.

\section{Community, Multicommunity and the Chicle Enterprise.}

The nine important towns of Peten all have the official status of pueblos. Each is a head of municipio although they do not meet the minimum requirements established by the Census definition. In services, size, and degree of modernization none compares with those trows of the same designation in Highland Guatemala. Important is the fact, however, that the official definition of what they are (city, pueblo, aldea, head of a municipio, or capital of the Department) has been incorporated into their view of life. So, Florentinos' view and public behavior toward others converge in support of their self-image. (Reina, 1964) From all the available information a theme which stands out for Flores is, "We Florentinos are people of the city, personally better endowed with the modern qualities to lead the Peten toward progress. We are civilized." Consequently, social behavior dictated by this assumption results in cultural differences preserved, by town rivalry, particularly among those towns whose people have the same origin and entertain similar levels of aspirations in life as those in Flores.

In support of this city image, Florentinos hold the generalized stereotype that the population of rural towns is illiterate, ignorant of world affairs, very provincial and, with the ex- 
ception of a few progressive leaders in each of the towns, rural people of Peten have no sense of obligation for the education of their children. "Rural town people do not even match the poorest class of people in Flores," said one leader. Any data which can demonstrate the validity of their argument is perpetuated by constant repetition.

Because it is boring and unbecoming to visit los pueblitos, it is not at all uncommon to find persons from Flores, particularly women, who seldom if ever have visited the towns. When questioned about this fact the standard answer is that "the pueblos are not attractive; that people hide when strangers arrive in town; and that it is not altogether safe to be a stranger." The backward life of the pueblos is demonstrated by the fact that the houses are not contiguous; there is lack of running water and electricity; the streets are muddy when it rains; and houses are surrounded by wide open space with domestic animals roaming about - it is muy triste.

Each of the towns has an annual celebration for their patron saint (Reina, 1960 Appendix I) ${ }^{7}$ and on that occasion the pueblo with the highest reputation - the most civilized - receives the highest number of visitors; those with poorer reputation are visited by people from "inferior" pueblos. Those coming to San José, for instance, are mostly from San Andrés, and San Joseños feel that they are the worst individuals who come to interrupt the celebration by being disrespectful to their costumbres after drinking in excess and fighting with San Joseños before rituals are completed. Flores people, on the other hand, like to think that their town's celebration is attended by many "good" puebleros. The town is, after all, "everyone's city and offers excitement for all, but only los más civilizados know how to take advantage of this opportunity." In all cases, however, only a handful of people attend fiestas of other towns.

The information collected from fifty interviews on the subject of town similarities and differences demonstrates, furthermore, that Florentinos are given a superior status and those town people with progressive ideas would prefer to reside in the city of Flores, if housing and office jobs are made available

7. There are no cofradia organizations here as are found in many of the Highland communities. 
to them. The city is "less boring and presents many advantages"; of special importance is the constant supply of food. The only informants showing little interest were those residing in the most competitive towns; namely, San Benito and the important aldea of Santa Elena, where the airport is located, When informants gave preference for pueblos, the ranking order correlated with the reputation enjoyed and the degree of progress - actually very little in all - achieved within the past fifty years. This was furthermore, meshed with the ethnic composition, the type of recent emigrants and the degree of social discrimination.

As has been stated previously, one's town composition and history determines what one is and, therefore, "passing" can be painful for sensitive individuals who are forced to move from a town with a "better" reputation to one considered backward. In the case of Florentinos, it is preferable to remain poor, barely surviving, than to migrate to a rural town. Such a move is considered to be only temporary, as when one is forced by an appointment (teachers or government employees). It is felt that Florentinos "should migrate only to Guatemala City." Any other move would be considered losing face. Frequently, anxiety runs high in this setting, particularly when all factors are working against the expected order of things. It is then that an anxious person may resort to political maneuvering, cuello and acomodo (influence seeking) in order to change the course of life. Thus, intrigue, gossip, and enmity begin and involve a good number of individuals who will continue the struggle until a point of adjustment is reached, perhaps after several years of tense relations.

Having described the social relation of towns and the degree of separation people feel toward each other, it is important to note the moment when the social separation by town takes a different turn. During the six-month rainy season contractors need large numbers of chicle gatherers, and it is the one time in the year when labor from most of the rural towns is contacted. Most of the important contractors reside in Flores and it is here that initial contacts are made. In line with the social pattern described, entrepreneur's first selection is based upon the town's reputation; but it is the one period of each year when all towns must come together with some understanding in order 
to take full advantage of the basic economic need. ${ }^{8}$ It is at this time that local leaders, government agents, private enterpreneurs, chicle gatherers, and speculators come together in a state of excitement seeking good profits.

The urgent need for labor brings out another phase in social interaction. It is during the temporada de chicle that one can argue for his personal worth even though inhabitants of his town may be generally known as contentious, untrustworthy and lazy. A chicle contractor lives hoping that this year he will find his luck. He likes to conceive a chiclero as a special kind of a person among the town's population who has the dual characteristics of ignominy and honesty. It is for the contractor to cultivate the chiclero and bring his better side into play for a period of four to six months. The isolation of chicle camps, the lack of reliable information, mismanagement from foremen, and the unavnidable state of boredom in the camp affects the chicleros' expectations and motivations, turning the relationship between contractor and laborer into a complicated vicious cycle, increasing friction and threats of violence. Consequently when some discontent has been reported, contractors do not venture into the camp, but administer from a distance, hoping for the best. It is here that the contractors and laborers think of each other again in terms of what they are via the ways of life of each other's towns. In those cases a potentially "good chiclero or contractor" as he has been known for some years, shows what basically he is supposed to be. Within the background of desconfianza toward each other there is a range of evaluation which goes from more to less as applied to each of the nine towns.

In this background. it becomes convenient for the chiclero to keep a mental record of contractors, and when a contractor is found through the years to be sagacious and perspicacious in his management, predictable, and politically powerful, "good" chicleros from a "good" town tend to seek work from him year after year. It is only then that chiclero and contractor do not become openly involved in stereotypes and grudges. Theirs, however, is looked upon as a private arrangement which

8 Peten is one of the most important chicle producing areas of the world and, therefore, the chicle enterprise is basic in the history of the region. It is this enterprise which has brought an urban orientation, but has kept the area underdeveloped. 
transcends that which is customary. A compadre relationship may also be established between laborer and contractor. This type, however, constitutes a very small number indeed. Interesting is the fact that during the great stress of searching for chicle gatherers contractor and laborer would like to dismiss the usual stereotype, resulting in an apparent equality of status upheld at the time of making the contracts (contracts are verbal), an event of great enthusiasm and optimism for all. It is at this time that the parties are apt to promise beyond possibilities, and frequently each claims special relations of confidence with the other. Chicleros may single out their case by criticizing others from their town who in the previous season behaved according to the stereotype. The chiclero plays on his skill and the contractor respects the skillful chiclero as well. The contractor recognizes that his personal economic success is at stake and depends upon the loyalty of his workers. But he knows that behind the individual's way of being stands the community's ways. He then has two levels with which to comply, and he fears that the ways of the community may have greater influence than the promises of the individual. Contractors hope that chicleros will not be demanding beyond their economic possibility to fulfill.

Astute contractors, with a reputation for cunning, face serious competition in the labor market. New contractors may be forced to recruit labor from the Vera Paz, but these outsiders come in with strange ways and are "predisposed to be crude, selfish, and hard on the contractors." The stories told by many ex-contractors, suddenly abandoned by their labor and plunged into bankruptcy, are just too many to detail. Such persons still claim that the trouble comes from ignorance combined with "the way these chicleros are in their own town." Because the job is not easy, some contractors tend to make liberal payments (from money advanced them from a government agency) in order to enganchar (to hook) the chiclero. There have been cases of chicleros receiving several thousands of dollars without any collateral, and since one cannot prosecute a person in debt, an interesting bargaining game is played between contractors and chicleros. In this game, there is no hesitation among relatives and friends to take labor away from each other by increasing the advances; and when la dignidad de la persona is hurt, a. contractor may risk beyond his means hoping that this year luck 
will be on his side. The national government through its agency (FYDEP) has centralized control over contractors, but traditionally chicleros have been suspicious of the contractor and all government arrangements. Chicleros feel unprotected and exploited in this system. The theme for all is, then, to get the best out of each season.

Chicle is a delicate economic game and many Flores families of the upper and middle social group who were contractors have lost everything after years of great prosperity. It is well known that through this chicle enterprise the town people have a certain degree of control over the destiny of Flores and the struggle is dramatic each year. It would seem to be the struggle of a frontier. The community culture is based upon each town, but the nation begins to set up rigorous controls and new social definitions. The traditional social elements are pulling to win but in the struggle the individual still finds security in his own place of residence. His town as a community orders his social relations and he continues his existence while perpetuating the ways of his town within the context of a multicommunity set-up. At the end of each chicle season the story repeats itself. Chicleros speak about contractors and contractors about the chicleros, not as identifiable individuals, but as persons from this or that town. Consequently, the evidence is clear to all that even under the pressure of this economic enterprise, each individual remains anchored above all to his community.

\section{Final and Practical Considerations}

It is evident that each Petenero experiences a first level of self-identification with his town of residence. It is also worth noting that their constant concern about each other's town is more than a routine or simple custom. The social elements help to preserve a hard cultural shell which points to a type of social organization identified here as community, supported in turn by the multicommunity context. Living in Peten demands the learning of the ways of each town in order to avoid social errors, and while questioning and listening to informants one is led to believe that the differences in community culture are substantial. Many values are not as basically different as $\mathrm{Pe}$ teneros would like to think. The difference lies in the degree of sophistication exercised in each town, which in turn fosters the social separation. The qualitative differences in values 
provide the impetus for the Peteneros' attitude toward each other and their actions which are centered in the context of the town. It is quite clear that presently the people's sense of destiny centers in their town first, but the very nature of the open-type community ties them and their fortune to the outside world. It is indeed the open-type community which permits the people to acknowledge the existence of other communities of which they may become members if forced to move. This stands in dramatic contrast to the strong sense of corporateness manifested in Chinautla which keeps its inhabitants apart and aloof.

The historical similarities in values of most of the communities outside San José can be demonstrated at times when migration takes place. Taking up a new residence does not have the serious consequences of cultural shock. The accommodation is brief if the person can endure the social discrimination based upon the town's differences. At such a time the person misses his community as a cultural entity, and "homesickness" may be evident. But migration is feasible in the opentype community, whereas one born in a corporate system finds it his duty to support and observe actively a tradition prepared by his ancestors. On the contrary, Peteneros seem to lack this kind of historical depth, feeling that modifications can and should be introduced..$^{9}$ There seems to be more excitement as they consider their own destiny, comparatively speaking.

The economic system of Peten can be partially blamed for the general stagnation of towns and their still precarious existence. The possibility of skilled labor and professional men finding employment is very limited; the market is quickly saturated. For instance, one good mechanic is sufficient to take care of the six trucks and three jeeps which are privately owned in the area. Many young people with aspirations are forced to migrate to Guatemala City. Migration, however, is not looked upon as an altogether desirable solution for an individual unless his entire family can follow him, and this is a rather difficult undertaking. A migrant alone in the city feels like an individual in exile, always thinking and planning to return, while feeling deep nostalgia for his "Itza-land." Some do return or seek a

9 Interestingly enough the pace of change in Chinautla (twelve kilometers from Guatemala City) is much slower than in Peten towns (one and one-half hours by air from the capital, which is the only means of direct transportation). 
job which can bring them in and out of Peten, but the identification with their town remains constant.

The town is, therefore, more than a political entity; it is truly a whole system. It is a community. And their identity with their own town has been so strong that frequently it has prevented Peteneros from working as a team. As a matter of fact, Peten history is full of illustrations of failures of new projects, clubs, developmental programs and the like. It has been in part due to the "pitfalls of cultural ignorance" (Goodenough, ibid., p. 484). Since the reader is familiar with some basic aspects of the culture, the pattern in the trajectory of each case is worth noting. There is at first an apparent success which results in great optimism for those directing a program. But after the first stage, there is usually a sudden collapse which comes as a shock. The question asked is always similar: "How is it that just when everything is working out well, there comes a collapse?" The inability to give proper weight to the community as a concept with all its cultural derivations seems to stand in the way of most projects initiated by outsiders. Towns possess no values as yet to guide them in pulling together as a team; they see nothing of value in each other's intellectual integrity. However, these differences are not readily seen nor are they presented to an outsider; the correct etiquette with outsiders, as among themselves, is to be agreeable and positive, reserving views and judgments until sufficient time has been give to speculation and sufficient thought has been given to the importance and meanig of a program. This is usually discussed among the members of a town who share its culture. Lack of action is in itself sufficient indication of a decision which should be interpreted as "Leave us alone and we will develop the ways of our town within our own possibilities." When improvements and changes are under consideration, each town feels equipped to initiate action, but this feeling has been mostly a theoretical position, since dissension is very frequent. There is insufficient strenglh in the religious or political institutions, social classes, or even the kinship system to bring the individuals of the community into full cooperation.

In conclusion, my concern in this paper has been to set forth descriptive facts accompanied by some general formulations to relate them and to bring out an implied theory of community social organization and culture. For the overall Latin American 
and Iberian social structure, pueblo (town) is a generalized political unit accompanied by an arrangement of values and world views. This brings about a system of meaningful social relations organized around the concept of "town." The intensity and concentration of a self-contained culture in each town varies. For a town with an extreme corporate type system of social relations, as is the Chinautla case, of overriding importance for the inhabitants are those elements which are intrinsically tied to the town history. There is a unilateral and firm identification with the town. Therefore, the town concept with the particular cognitive framework that it carries in each case, constitutes an organizing principle for living. Here is the real meaning of community. In light of the many town and village studies in Western Europe and Latin America, "community" as a principle of social organization deserves special attention. Traditional anthropology with its sample biased toward smallscale "tribal" societies, has emphasized other principles which in fact are not empirically central in large areas of the world.

When community exists, one of the most frequent manifestations is rivalry between towns based on perceived and often magnified "cultural differences." This serves to heighten the feelings of identification and ethnocentrism. However, the necessity of co-existing in a still underdeveloped and isolated tropical environment and the desire to live as "civilized people should" forces Peteneros to acknowledge certain common elements among them but with no intention to overlook all those elements which form the framework of their respective towns. The situation is frequently awkward socially when individuals from different towns meet. Theoretically, if a town is a community, it is in full control of its destiny, but the total situation of the Peten region is such that it curtails the exercise of cultural independence as is prescribed by a transplanted corporate social system. As each Peten town perpetuates its own identity to the degree described in this paper, cultural merging becomes difficult. Therefore, from a practical viewpoint, Peteneros realize the need to coordinate their efforts in some areas of their daily activities, and communication among them is very complete inasmuch as they share much of the cultural content. This serves to unite them as Peteneros and makes them, by the same token, different from others - for instance, from Guatemalans. Under these conditions, it is not difficult to detect a set of working 
principles supporting a special way of perceiving and interacting with each other. This social organization of intercommunity relations goes beyond that which derives simply from the political structure of the Department of Peten or as seen in the business transactions of dealers. It is a feeling of an overall togetherness based upon the "strong" cultural peculiarities of each town. This total system of articulation among inter-related communities I wish to identifify as multicommunity.

Summarizing the dynamics of the case, people from different origins grouped themselves together in towns modeled after the Iberian tradition. Each town strived to maintain a corporate type community but by their historical destiny in an isolated jungle area there was a need to harmonize their relations and, in a real sense, become part of each other. But the fact remains that the complexes of town, community, and multicommunity still appear as separable entities. As history moves on, it will be interesting to continue studying the principles in terms of which changes occur as well as to document the precise conditions under which existing lines of demarcation begin to fade. As a case, Peten constitutes an empirical reality with interesting theoretical implications for understanding modern Latin American social structure. Finally, the case tells us much about the nature of the Iberian heritage which is still undergoing adaptations in the New World. ${ }^{10}$

\section{BIBLIOGRAFIA}

Goodonough, Ward H.

1964 Cooperation in change. Russell Sage Foundation. New York. Murdock, George Peter

1949 Social Structure. The MacMillan Company. New York.

Pit'r-Rivers, J. A.

1961 The People of the Sierra. Phoenix Books, The University of Chicago Press. Chicago.

REDFIELD, Robert

1958 The Little Community: Viewpoints for the Study of a Human Whole. The University of Chicago Press. Chicago.

10 The reader is referred to the excellent study of J. A. Pitt-Rivers, The People of the Sierra, for the background of an Andalucian pueblo. 
Reina, Rubén E.

1959a Two Patterns of Friendship in a Guatemalan Community. American Anthropologist, Vol. 61, No 1. Menasha.

$1959 b$ Political Crisis and Cultural Revitalization: The Guatemalan Case. Human Organization, Vol. 17, No 4, pp. 14-18. Ithaca, N. $Y$.

1960 Chinautla. A Guatemalan Indian Community: A Study in the Relationship of Community Culture and National Change. Middle American Research Institute, Publication 24, Tulane University. New Orleans.

1963 Also in: Guatemala Indigena, Instituto Indigenista Nacional, N? 9. Guatemala. (Spanish version).

1961a The Abandonment of Primicias by Itza of San Jose, Guatemala and Socotz, British Honduras. Tikal Reports, No 10. Museum Monographs, The University Museum of Pennsylvania. Philadelphia.

$1961 b$ Also in: Guatemala Indigena, No 2. Guatemala. (Spanish version).

-1962a The Ritual of the Skull in Peten, Guatemala. Expedition, Vol. 4, No 4, University of Pennsylvania Museum. Philadelphia.

$1962 b$ Also in: Guatemala Indigena, No 4. Guatemala. (Spanish version).

1964. The Urban World View of a Tropical Forest Community in the Absence of a City, Peten, Guatemala. Human Organization, Vol. 24, Winter, $N^{\circ}$ 4, pp. 265-278. Ithaca, N. Y.

1966 Each Walks Alone. Bubbs-Merril Co., Inc. New York. (In press).

Soza, José María

1957 Pequeña Monografía del Petén. Ministerio de Educación Pública. Guatemala.

WoLF, Eric

1955 Types of Latin American Peasantry: A Preliminary Discussion. American Anthropologist, Vol. 57, No 3, Part 1, pp. 452 472. Chicago.

Young, Frank W.

1964 Location and Reputation in a Mexican Intervillage Network. Human Organization, Vol. 23, Spring. No 1, pp. 36-41. Ithaca, N. $\mathrm{Y}$. 


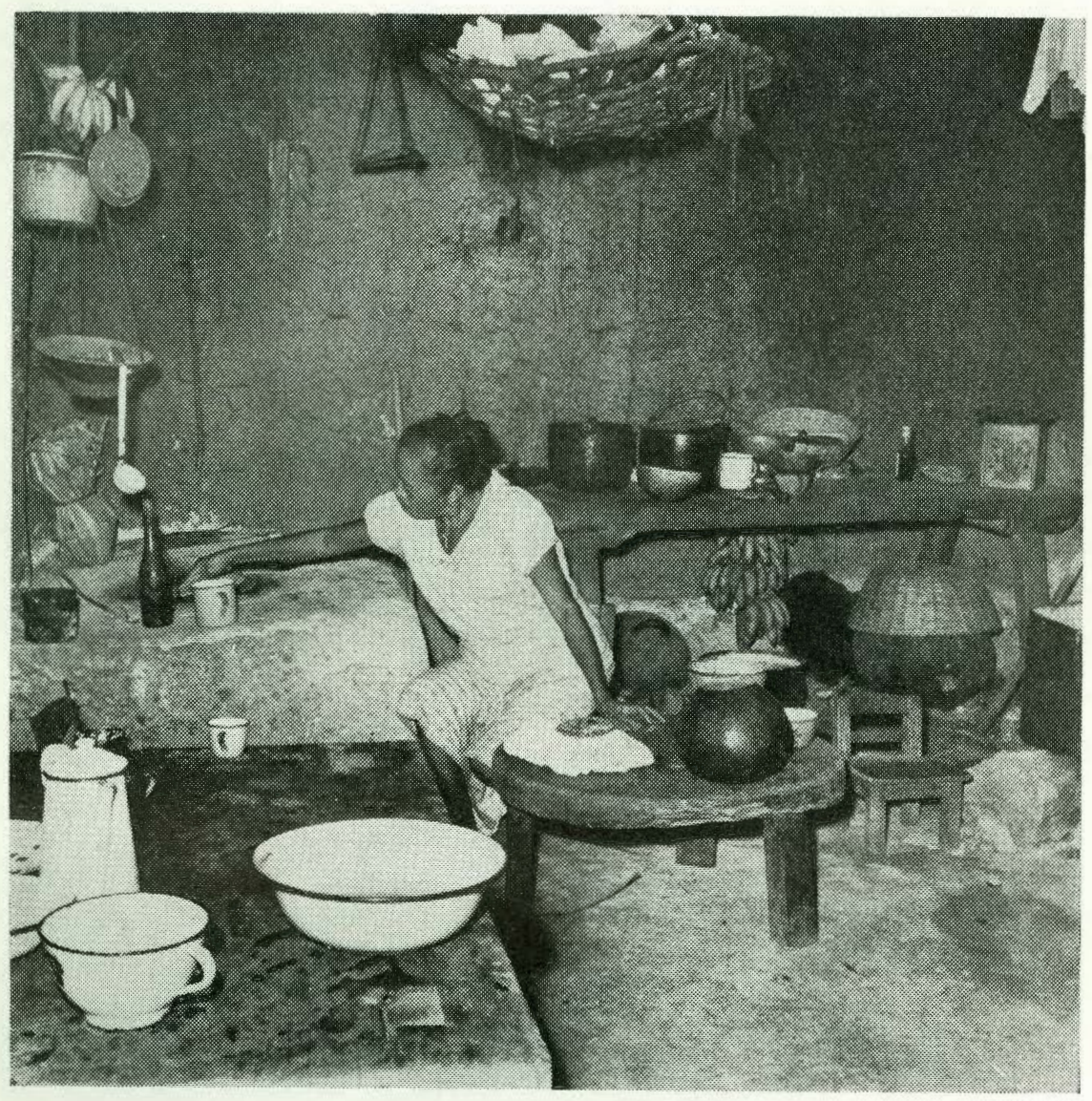

FIg. 1. A maya housewife in San José. 


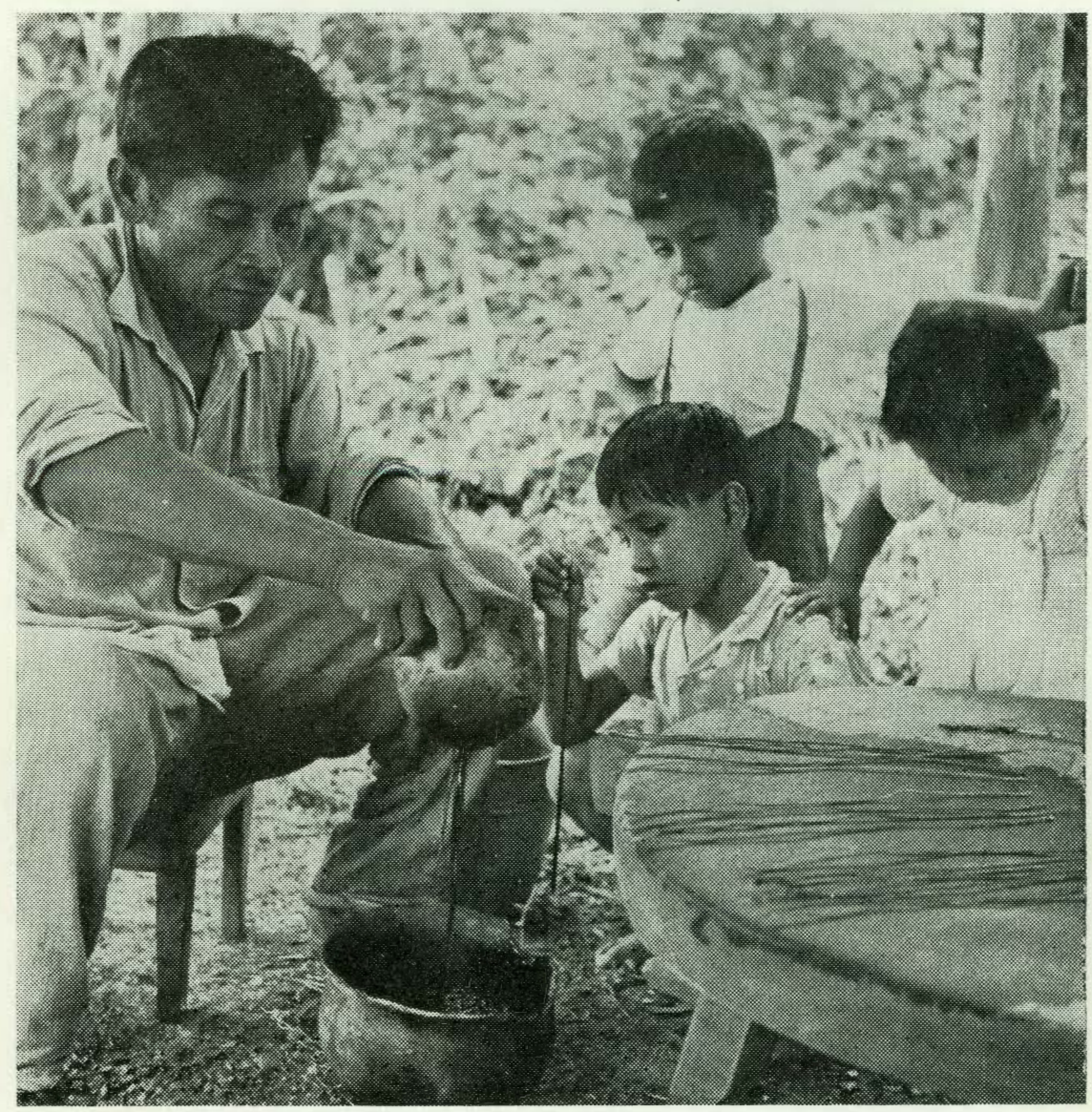

Fig. 2. An Itza man preparing candles for a ritual. 


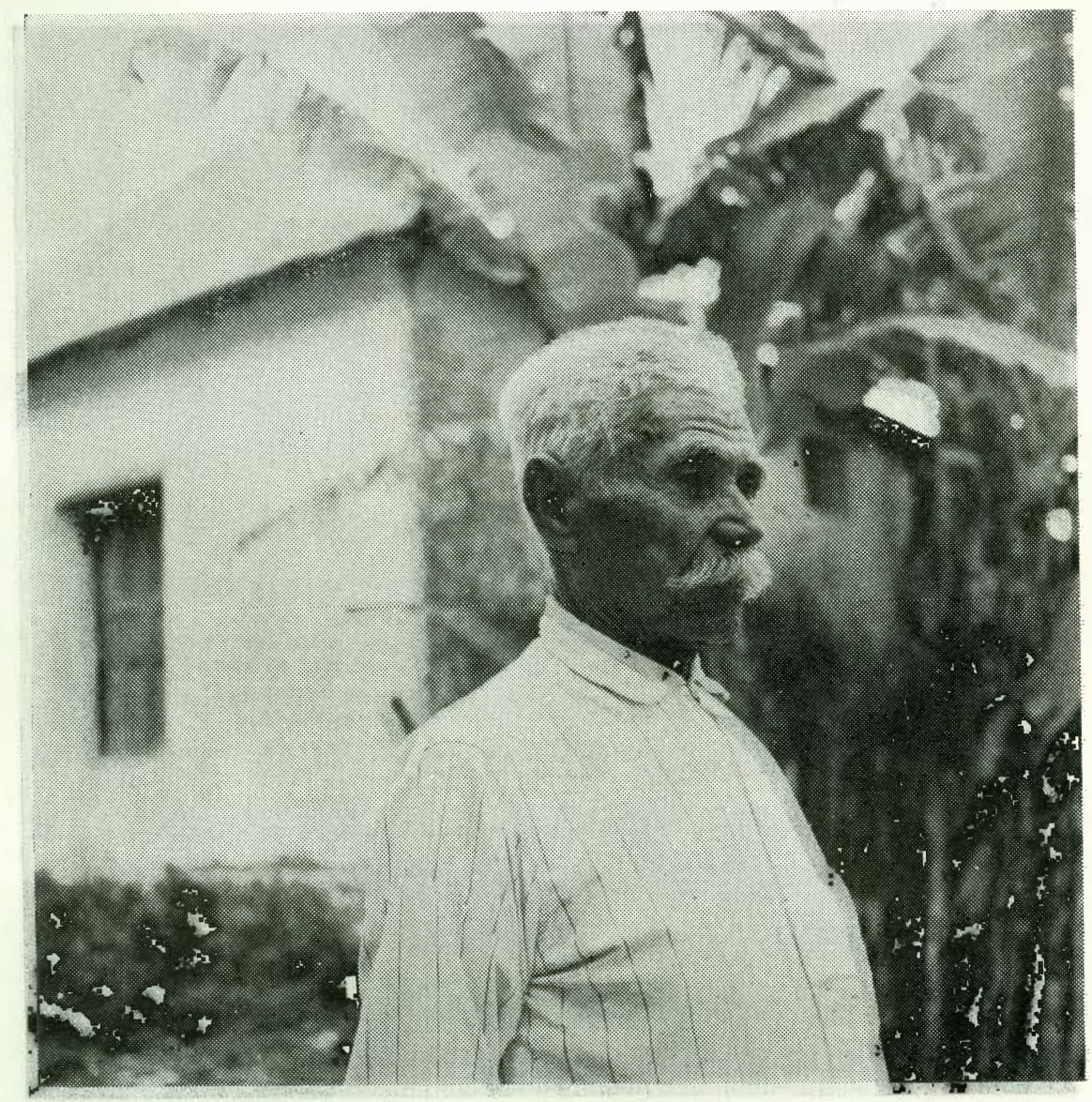

Fic, 3. A typical resident of Flores who can trace his Spanish heritage via Yucatan. 